\title{
Endophytic Fungal Volatile Compounds as Solution for Sustainable Agriculture
}

\author{
Amine Kaddes ${ }^{1, *}$, Marie-Laure Fauconnier ${ }^{2}$, Khaled Sassi ${ }^{3}$, Bouzid Nasraoui ${ }^{4}{ }^{\mathbb{D}}$ and \\ Mohamed-Haïssam Jijakli ${ }^{1}$ \\ 1 Urban and Integrated Plant Pathology Laboratory, Gembloux Agro-Bio Tech (GxABT), University of Liège, \\ 5030 Gembloux, Belgium; mh.jijakli@uliege.be \\ 2 General and Organic Chemistry Unit, Gembloux Agro-Bio Tech (GxABT), University of Liège, \\ 5030 Gembloux, Belgium; marie-laure.fauconnier@uliege.be \\ 3 Department of Agronomy and Plant Biotechnology, National Agronomic Institute of Tunisia, \\ University of Carthage, Tunis 1082, Tunisia; khaledsassi1@gmail.com \\ 4 RL/Biogressors and Integrated Protection in Agriculture, National Agronomic Institute of Tunisia, \\ University of Carthage, Tunis 1082, Tunisia; nasraouibouzid2012@gmail.com \\ * Correspondence: amine.kaddes@doct.uliege.be; Tel.: +32-81-622-433; Fax: +32-81-622-432
}

Received: 16 February 2019; Accepted: 12 March 2019; Published: 18 March 2019

\begin{abstract}
Endophytic fungi produce various mixtures of carbon-based compounds, which are known as volatile organic compounds (VOCs). Research regarding the use of VOCs as pesticide substitutes has garnered much attention. This review summarizes the recent knowledge about VOCs regarding their origin and chemical properties and emphasizes their antimicrobial potential against a wide variety of agricultural pathogens. Several studies have highlighted the importance of VOCs as antimicrobial agents. Nevertheless, the application of VOCs in biofumigation methods still requires the advanced evaluation of their phytotoxicity.
\end{abstract}

Keywords: volatile organic compounds; fungi; endophytic fungi; pathogenic

\section{Introduction}

The control of pre- and post-harvest diseases is essential to maintain the quality of crops and agricultural products. Currently, while the application of pesticides is the most popular way to control several pathogens, there is irrefutable evidence that the use of these products is harmful to humans and the environment, besides causing the proliferation of pathogen-resistant strains [1,2]. In this context, the development of a biopesticide strategy, as an alternative to conventional pesticides, has become a research topic of great interest. Biocontrol methods are based on the use of either living organisms or natural substances produced by these organisms (pheromones, plant extract) [3]. The exploitation of natural substances, such as essential oils, seems to be a promising approach for controlling post-harvest diseases caused by different micro-organisms, producing safe foods, and reducing environmental pollution. Moreover, natural substances could effectively control the growth of certain pesticide-resistant microorganisms [4]. In the context of biocontrol methods, it has been reported that several endophytic fungi are able to produce volatile organic compounds (VOCs) [5,6]. Endophytic fungi are defined as fungi that spend the whole or part of their lifecycle colonizing inter-and/or intra-cellular systems, especially leaves, stems, and roots, without causing any apparent disease symptoms in their hosts [7,8]. Endophytic fungi play important roles in plant micro-ecosystems. Reports have revealed that over 1 million fungal endophytes have been found in various plant micro-ecosystems [9]. Endophytic fungi provide many benefits to their hosts by enhancing host growth and defense against pathogens. In addition, many endophytic fungal strains, such as Trichoderma, Noduliosporium, and Muscodor sp., can modulate the 
plant defense systems by inhibiting and reducing the load of fungal pathogens [10]. These benefits are principally attributed to the mixture of VOCs produced by endophytic fungi. In fact, there is an estimated 322 identified secondary metabolites secreted by endophytic fungi. These metabolites are derived from different fungal metabolism pathways and consist of a diverse range of compounds, including alkaloids, terpenoids, quinones, peptides, xanthones, and phenols [11,12]. Owing to their small size and high vapor pressure, VOCs can diffuse easily through the atmosphere and soil [13]. It is known that these compounds play an important role in communication between fungi and other organisms in the ecosystem. In addition, these molecules have shown promising bioactivity potential against a wide range of pathogens [14,15]. Hence, these molecules are used as part of biocontrol strategies, in what is termed mycofumigation, to inhibit the growth of numerous plant pathogens [16,17].

As a single review cannot discuss the findings of the different studies on fungal VOCs, this review focuses only on endophytic fungal VOCs, with an emphasis on their structure, properties, production, and biological activities.

\section{Volatile Organic Compounds (VOCs)}

VOCs are hydrophobic, organic molecules with a low molecular weight $(<300 \mathrm{Da})$ and high vapor pressure ( $\geq 0.01 \mathrm{kPa}$ at $20^{\circ} \mathrm{C}$ ) [18]. Due to their physico-chemical properties, these molecules can cross plant cell membranes; therefore, they play a very important role in the functioning of soil ecosystems $[13,19,20]$. VOCs are of anthropic (refining, evaporation of organic solvents, unburned, etc.) or natural origins (emissions by plants, animals, and microorganisms). The majority belong to five chemical groups - terpenoids, fatty acid derivatives, benzenoid compounds, phenylpropanoids, and amino acid derivatives. They play a very important role in the control of several fungal pathogens $[20,21]$.

Their biosynthesis is highly dependent on the availability of carbon, nitrogen, sulfur, and energy provided by primary metabolism. Four precursors are known to be implicated in these biosynthetic pathways-PEP, E4P, pyruvate, and acetyl-coA. The four major metabolic pathways, namely the shikimate/phenylalanine, the mevalonic acid (MVA), the methylerythritol phosphate (MEP), and lipoxygenase (LOX) pathways, involve different enzymatic reactions and lead to the production of benzenoids/phenylpropanoids, sesquiterpenes, monoterpenes, hemiterpenes, diterpenes, volatile carotenoid derivatives, and methyl jasmonate/green leaf volatiles (Figure 1) [20].

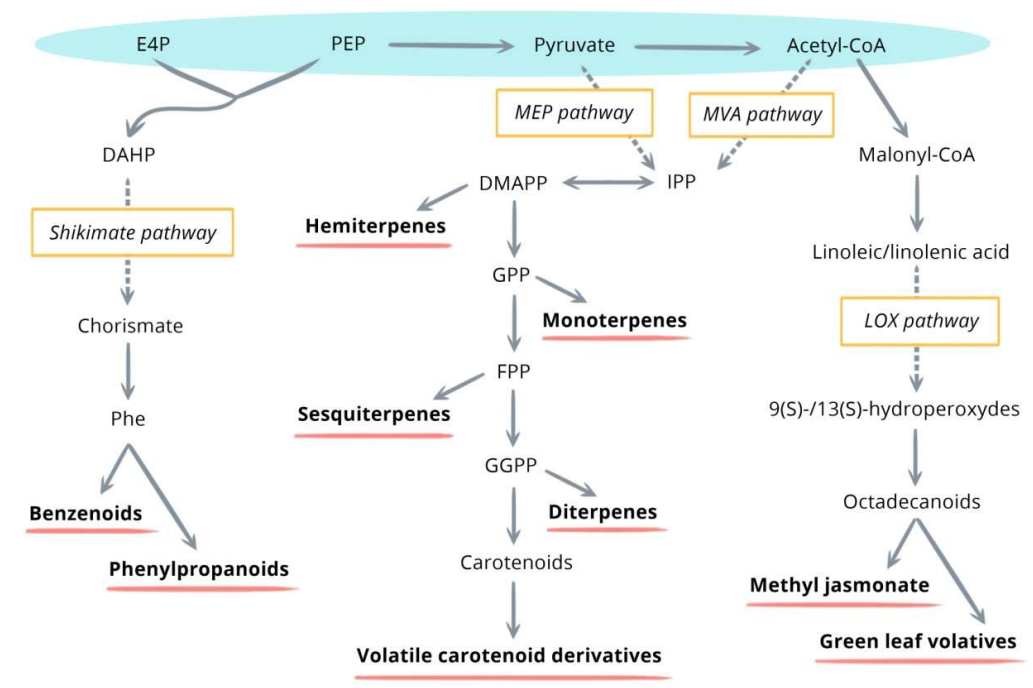

Figure 1. General overview of the major metabolic pathways inducing the synthesis of volatile organic compounds (VOCs.) [20]. DAHP, 3-deoxy-D-arabinoheptulosonate-7 phosphate; DMAPP, dimethylallyl pyrophosphate; E4P, erythrose 4-phosphate; FPP, farnesyl pyrophosphate; GGPP, geranylgeranyl pyrophosphate; GPP, geranyl pyrophosphate; IPP, isopentenyl pyrophosphate; NPP, neryl pyrophosphate; PEP, phosphoenolpyruvate; Phe, phenylalanine. 
As mentioned above, VOCs are secreted by endophytic fungi. In fact, these microorganisms are able to interact with their host plants and produce a mixture of VOCs molecules. The mixture constitutes "sentences" that allow plants to transmit complex signals and, thus, communicate with their environment. The main functions that can be performed by VOCs emitted by plants or fungi are defense against herbivores and pathogens, communication between different organs of the plant or with other plants, and attraction of beneficial agents (for example pollinators, seed dispersers, and microorganisms) $[15,21,22]$. Therefore, this review is only focused on the current state of knowledge on endophytic fungal VOCs with regard to their potential bioactivity for use against fungal plant pathogens.

\section{Antifungal Effect of Volatile Organic Compounds Produced by Endophytic Fungi}

Several studies highlight the important antifungal role of VOCs compounds. These molecules could have different chemical structures and play a potential role in plant defense against fungal diseases. In their report, Lee et al. [23] demonstrated that, during in vitro and in vivo assays, an antifungal volatile compound produced by Oxyporus latemarginatus was found to have inhibitory action against a broad spectrum of pathogenic fungi, including Alternaria alternata, Colletotrichum gloeosporioides, and Fusarium oxysporum f. sp. Lycopesici. The antifungal compound was identified through Gas Chromatography-Mass Spectrometry (GC-MS) as 5-pentyl-2-furaldehyde [23]. Moreover, O. latemarginatus EF069 was capable of inhibiting the growth of Botrytis cinerea and Rhizoctonia solani, which can cause post-harvest apple decay and root rot of moth orchids, respectively. Similarly, Lee et al. [23] revealed that $50 \mathrm{~g}$ of wheat bran/rice inoculated with O. latemarginatus EF069 effectively reduced the development of post-harvest apple rot caused by B. cinerea. In their study, Malmeirca et al. [24] established direct confrontation assays between Trichoderma strains and the pathogen $B$. cinerea. For this purpose, agar plug cuts of each fungi were placed in potato dextrose agar plates and incubated at $28^{\circ} \mathrm{C}$ in the dark. The radial growth of Trichoderma. arundinaceum was observed until it surrounded the pathogen colony. Results revealed that the growth of $B$. cinerea was controlled by $T$. arundinaceum, using trichodiene. This indicates VOCs indirectly inhibits B.cinerea by inducing the expression of defense genes encoding the production of salicylic and jasmonic acids and by interacting with hydrolytic enzymes [24]. Trichoderma sp. have also been widely used as biological control agents for the control of soil-borne pathogens. VOCs emitted by Trichoderma harzianum resulted in $67 \%$ growth inhibition of Colletotrichum capsici, whereas Trichoderma saturnisporum and Trichoderma reesei inhibited $59.3 \%$ and $30.4 \%$ of C. capsici, respectively [25]. In the same context, F. oxysporum can inhibit the growth of $B$. cinerea. It is also responsible for the total inhibition of three fungal species, Rhizoctonia solani, Penicillium digitatum, and Aspergillus niger. This has been confirmed by inhibition of pectin methylesterase, cellulase, and polyphenols oxidase secretions [26]. This antifungal activity could be attributed to terpenes, principally limonene, $\beta$-phellondrene, and 1,8-cineole (synonym: eucalyptol) secreted by the microorganism. In addition to terpene VOCs secretion, endophytic fungi can emit alcohols and carboxylic acids. For example, Phomopsis sp. produce a unique blend of VOCs, which is composed of sabinene, 1-butanol, phenethyl alcohol, 1-propanol, and acetone. This fungus has been isolated as an endophyte associated with Odontoglossum sp. (Orchidaceae) in a forest in northern Ecuador. It has been shown that these molecules inhibit a broad spectrum of fungi from different taxonomic groups, such as Deuteromycetes, Ascomycetes, and Oomycetes.

This section emphasizes the description of VOCs compounds secreted by two important endophytic fungi species, Muscodor and Noduliosporium. Muscodor has been the focus of many studies since it produces VOCs known for having lethal effects against a wide variety of pathogenic fungi. Currently, the mixture of VOCs, produced by Muscodor albus is used as a primary screening tool to discover new Muscodor species with potent VOCs production. To date, $14 \mathrm{Muscodor}$ species have been described: Muscodor albus, Muscodor roseus [27,28], Muscodor vitigenus [29], Muscodor crispans [30], Muscodor yucatanensis [31], Muscodor fengyangensis [32], Muscodor cinnanomi [33], Muscodor sutura [34], Muscodor musae, Muscodor oryzae, Muscodor equiseti, Muscodor suthepensis [35], and recently Muscodor kashayum [36] and Muscodor tigerii [37]. Muscodor species have been isolated in South America, the USA, 
and southeast Asian countries, including Thailand, China, and, most recently, India. The genus Muscodor effectively controls several pathogenic fungi. M. albus inhibits the growth of Rhizoctonia solani and Phytophthora capsici responsible for pepper root rot. These species also inhibit the germination of teliospores Tilletia horrida, Tilletia indica, and Tilletia tritici. Mercier et al. [38] showed that the VOCs spectrum emitted by two strains, Muscudor CZ-620 and strain MFC2, effectively controlled fungal rot of multiple fruits. The VOCs mixture was analyzed by GC with Flame Ionization Detector and results showed that it was mainly composed of isobutyl alcohol, 2-methyl-1-butanol, and isobutyric acid [38]. Other Muscodor species have been the subject of several studies. Muscodor cinnamomi CMU-Cib461 inhibited the growth of Rhizoctonia solani, which could induce leaf blight, leaf spot, damping-off, and leaf rot [39]. In the same context, M. kashayum inhibited the growth of Cercosporabeticola, Colletotrichum gloesporioides, Mycosphaerella fijiensis, Chaetomium heterosperum, and Fusarium oxysporum. The analysis of volatiles compounds emitted by $M$. kashayum was carried out by a solid phase microextraction coupled with GC-MS. For this purpose, a solid phase microextraction syringe was used to trap the volatile compounds emitted by a 10-day-old culture of Muscodor following the method of Ezra et al. [36,40]. Subsequently, VOCs were analyzed by GC-MS. Results revealed that the mixture contains 23 volatile compounds which were identified by comparing the GC-MS spectra. The most abundant of all the volatile compounds produced were cyclohex-3-en-1-ol and $\beta$-bisabolol.

These volatiles produced by $M$. kashayum are unique, and have not been previously reported by any other Muscodor species, which predominantly produce esters of isobutyric acid, methyl acetate, ethyl-2-methylbutyrate, and alcohol [34,36].

To highlight the antifungal potential of VOCs emitted by endophytic fungi, Strobel et al. [41] introduced the concept of mycofumigation. Mycofumigation is a new biological control alternative for post-harvest diseases of fruit and vegetable rots. However, its effectiveness depends on the fungal species, the amount of inoculum used, and the type of post-harvest disease. Actually, this method is used for the treatment of fruits in storage rather than controlling soil borne pathogens. In this context, soils are inoculated with a M. albus preparation in order to preclude the growth of pathogens [17,42]. Field bioassays for the evaluation of Muscodor albus efficacy against three pathogenic fungi of sugar beets, Rhizoctonia solani, Pythium ultimum, and Aphanomyces cochlioides, have been established. Briefly, sterilized barley seeds were inoculated with M. albus. After incubation at $25^{\circ} \mathrm{C}$ for three weeks, the inoculated grains of barley were dried and ground to a sawdust texture. After that, the preparation was spread over the surface of the soil and covered with black plastic mulch and loose soil. After one week, the soil preparation containing Muscodor was added as a top layer onto pots inoculated with pathogens. Sugar beet seeds were planted in different plots and placed in a greenhouse. The amount of healthy sugar beet seedlings was estimated after 14, 21, and 28 days of plantation. Results revealed that mycofumigation of infested soil with $M$. albus improved the healthy seedling establishment of sugar beets [17]. On the basis of several reports highlighting the potential antifungal activity of Muscodor, the industrial company AgraQuest, of Davis, CA, USA, is currently undertaking full-scale development of M. albus for several agricultural applications [43]. Different aspects related to the optimization of the formulation, cost-effectiveness ratio, and scale-up of mycofumigation with Muscodor are underway. This may limit the utilization of others hazardous fumigants such as methyl bromide chloropicrin mixtures [44,45]. In their study, Suwannarach et al. [35] established an in vivo assay for investigating fumigation activity of $M$. suthepensis. Briefly, the sterilized surface of tangerine fruits was inoculated with spore suspensions of the pathogenic fungi $P$. digitatum. Next, the infected fruits were stored at $25{ }^{\circ} \mathrm{C}$ in plastic boxes containing inoculum of $M$. suthepensis. After $24 \mathrm{~h}$, the fungal inoculum was removed, and boxes were kept at $25{ }^{\circ} \mathrm{C}$ for nine days. The diameters of decay lesions were measured during the incubation period. Results showed that a $12 \mathrm{~h}$ fumigation with $30 \mathrm{~g}$ per $4 \mathrm{~L}$ of a $M$. suthepensis inoculum completely controlled mandarin fruit rot caused by the pathogenic fungi P. digitatum [39]. Similarly, a $24 \mathrm{~h}$ fumigation with $30 \mathrm{~g}$ per $11.4 \mathrm{~L}$ of rye grains of $M$. albus was required for the complete control of $P$. digitatum. Moreover, $24 \mathrm{~h}$ of fumigation with $30 \mathrm{~g}$ per $11.4 \mathrm{~L}$ of $\mathrm{M}$. albus inoculum controlled blue mold caused by Penicillium expansum and gray mold caused by B. cinerea of 
apples. Fumigation with $140 \mathrm{~g}$ per $11.4 \mathrm{~L}$ of M. albus inoculum controlled brown rot caused by Monilinia fructicola. In their report, Saxena et al. [37] revealed that growth of Alternaria alternans and Cercospora beticola were totally inhibited by volatile compounds secreted by Muscodor tigerii. In other studies, it has been demonstrated that the VOCS mixture produced by Muscodor CZ-620 and MFC2 limited fungi rot in a wide range of fruits. Recently, Hutchings et al. [46] identified a novel VOC molecule, N-methyl-N-nitrosoisobutyramide (MNIBA). This thermolabile molecule was identified by GC-MS analysis when a low-injection temperature $\left(140^{\circ} \mathrm{C}\right)$ was applied. It has been reported that the toxicity of M. albus is directly correlated to the MNIBA concentration in the VOCs mixture produced by this fungal strain. MNIBA is known to cause DNA damage by methylation. The spontaneous decomposition of MNIBA compounds generates, principally, iso-butyric acid and methyl-diazohydroxide, which could be converted, in a second step, to methyl-diazonium. This compound induces DNA methylation and, therefore, the generation of NO radicals, which are responsible for the chemical nitrosylation of amides. GC-MS analysis of COVs produced by Muscodor revealed a high amount of a volatile compound derived from isobutyric acid. The higher bioactivity of MNIBA is attributed to the presence of this compound. Hence, Muscodor species are considered as potential agents that could be used in biofumigation.

Nodulisporium sp. are characterized by their resistance to VOCs emitted by M. albus. This resistance is assigned to the ability of these fungi to produce VOCs with important antifungal properties [47]. Suwannarach et al. [48] showed that the strain Nodulisporium sp. CMU-UPE34 was able to produce 31 VOCs. Analyses of the VOCs mixture by GC-MS revealed that it consisted mainly of alcohols, acids, esters, and monoterpenes. Among these molecules, eucalyptol (synonym: 1,8-cineole) was the most abundant volatile compound. In the second part of this work, an in vivo assay for fumigation activity of volatile compounds produced by Nodulisporium was carried out. For this purpose, sterilized surfaces of citrus fruits were inoculated with different pathogenic fungi and incubated in plastic boxes. Next, boxes were inoculated with Nodulisporium sp. CMU-UPE34. After $48 \mathrm{~h}$ of incubation at $25^{\circ} \mathrm{C}$, the fungal inoculum was removed, and the boxes were re-stored in the same conditions. After one week, the diameters of decay lesions by each pathogen were measured. Results revealed that the mixture of VOCs inhibited the growth of different pathogenic fungi with the inhibition yield ranging from 47\%-93\% [48]. In addition, in vivo tests have shown that Nodulisporium sp. CMU-UPE34 controlled the growth of Penicillium digitatum and Penicillium expansum and caused completely inhibition of Aspergillus fumigatus and Rhizoctonia solani [49]. Other studies demonstrated that the strain Nodulisporium sp. CMU-UPE34 efficiently inhibited the proliferation of P. digitatum, P. expansum, Aspergillus fumigatus, and R. solani [50]. Analysis of the VOCS mixture secreted by this fungal strain revealed that it was mainly composed of 1,8-cineole and terpinen-4-ol. The compound 1,8-cineole can cross cellular membranes and induce damage in different cellular organelles. Moreover, it has been shown that there is a synergistic effect between 1,8-cineole and terpinen-4-ol. In fact, 1,8-cineole can easily cross the cellular membrane and, therefore, facilitate the entry of terpinen-4-ol into the intracellular medium [51]. Other studies have reported that the fumigation of jasmine rice, which is a variety of Oryzaindica, with $50 \mathrm{~g}$ and $60 \mathrm{~g}$ of Nodulisporium sp. CMU-UPE34 culture and the fumigation of wheat/rice bran with $50 \mathrm{~g}$ of Nodulisporium sp. CF016 controls cabbage green mold completely and suppresses the development of gray and blue mold lesions by $88 \%$ and $76 \%$, respectively $[39,52,53]$.

To better understand the antifungal effect of VOCs on pathogenic fungi, researchers have used artificial molecules. They compared them with VOCs secreted directly from fungi. According to the study established by Syed et al. [54], in comparison with fungal VOCs, a mixture of synthetic VOCs consisting of pentan-2-one, hexan-3-one, 1,8-cineole, $\beta$-farnesene, and propanoic acid was more effective against Phytophthora palmivora, Phytophthor cinnamomi, Pythium ultimum, R. solani, Sclerotinia sclerotiorum, and B. cinerea [54]. In addition, a comparative study between the natural thujospen emitted by Penicillium decumbens Thom C. and commercial thujospen showed that they had similar antifungal bioactivity against the five strains tested-Aspergillus sydowii, Eurotium herbariorum, Polytrichum macroclada, Penicillium hirsutum, and P. decumbens [55]. In addition, Singh et al. [56] showed 
that the use of the median effective concentration (EC50) of an artificial mixture similar to the VOCs emitted by Phomopsis sp. completely inhibited the growth of Colletotrichum lagenarium and Trichoderma viride [56]. However, natural VOCs showed no inhibitory effect on T. viride and C. lagenarium. This suggests that some VOCs emitted by Phomopsis sp. but not identified through GC-MS due to low concentrations that do not reach the detection threshold, may influence the inhibitory effect on the fungus [56]. In the same context, the use of a pure chemical or a mixture of several chemicals (butyl, ethyl acetate, and ethanol representing the VOCs spectrum naturally emitted by Ceratocystis fimbriata), in proportions calculated using GC-MS analysis, showed no inhibitory effect. According to the authors, the inhibition may be a synergistic effect of all VOCs of C. fimbriata, including molecules not detected using current identification methods [57]. A similar observation was recorded for another VOCs mixture produced by Muscodor sp.

\section{Phytoxicity of Volatile Organic Compounds}

Despite all the promising results, the question of phytotoxicity depended on the use of VOCs. Numerous studies have shown strong relationships between VOCs and phytotoxicity [58]. As early as 1965, Muller confirmed that terpenic VOCs of Sarracenia leucophylla reduced the number of rootlets and the germination of hypocotyl seeds of Cucumis sativus (L.) [59]. Inderjit et al. [60] revealed that species richness of plants was much lower due to VOCs produced by Ageratina adenophora litter. In the same context, He et al. [61] showed that dead leaf water and decomposition of residues around Eucalyptus urophylla contained VOCs of the sesquiterpenes 1,8-cineole and terpinene-4-ol, and, respectively, represented $19 \%$ and $39 \%$ of the water-soluble mixture. The synthetic forms of these two volatile compounds inhibited the germination of some cereals, and the growth of some weeds [61]. Lee et al. [62] studied the phytotoxicity of alcoholic VOCs. Exposure of Arabidopsis thaliana (L.) grains and plants to a concentration of 1 PPM 1-octanol, 2-octanol, 3-octanol, and 1-octen-3-ol synthetic forms showed no effect on germination. Nevertheless, these molecules caused a growth retardation of the radical part. In the same study, different plant and ethanol samples were examined, as well as their morphological changes or modifications. The chlorophyll concentration and root growth of treated plants was also measured. These results are confirmed by Ogura et al. [63] who tested the phytotoxicity of alcohols emitted by a non-endophytic fungi P. expansum. The results were analyzed with a concentration of $100 \mathrm{mg} / \mathrm{L}$, completely inhibiting the germination of 15 types of Brassicaceae, including six radish varieties. This information could also be important when considering the phytotoxic effect of VOCs, including their dose, origin, chemical nature, and mode of application. Table 1 summarizes proprieties of the most important endophytic fungi VOCs. 
Table 1. Overview of VOCs molecules, their origins, and antimicrobial effects.

\begin{tabular}{|c|c|c|c|c|c|c|}
\hline $\begin{array}{l}\text { Endophytic Fungi } \\
\text { Producing VOCs }\end{array}$ & VOCs Effects & $\begin{array}{c}\text { Microorganisms Inhibited } \\
\text { by VOCs }\end{array}$ & VOCs/CAS Number & Molecular Formula & Hosts & References \\
\hline Fusarium oxysporum can-* 46 & $\begin{array}{l}\text { Inhibition of } \\
\text { mycelium }\end{array}$ & $\begin{array}{c}\text { Aspergillus flavus } \\
\text { Aspergillus parasiticus } \\
\text { Botrytis cinerea } \\
\text { Colletotrichum siamense } \\
\text { Fusarium graminearum } \\
\text { Fusarium oxysporum f.sp. } \\
\text { vasinfectum } \\
\text { Magnaporthe oryzae } \\
\text { Monilinia fructicola }\end{array}$ & $\begin{array}{c}\text { Farnesol (4602-84-0) } \\
\text { 3-caryophyllene (87-44-5) } \\
\text { Limonene (138-86-3) } \\
\text { Hexanoic acid (142-62-1) } \\
\text { Octanoic acid (124-07-2) }\end{array}$ & $\begin{array}{c}\mathrm{C}_{15} \mathrm{H}_{26} \mathrm{O} \\
\mathrm{C}_{15} \mathrm{H}_{24} \\
\mathrm{C}_{10} \mathrm{H}_{16} \\
\mathrm{C}_{6} \mathrm{H}_{12} \mathrm{O}_{2} \\
\mathrm{C}_{8} \mathrm{H}_{16} \mathrm{O}_{2}\end{array}$ & Gossypium herbaceum & [64] \\
\hline Hypoxylon sp. & $\begin{array}{l}\text { Inhibition of } \\
\text { mycelium }\end{array}$ & $\begin{array}{c}\text { Botrytis cinerea } \\
\text { Ceratocystis ulmi } \\
\text { Cercospora beticola } \\
\text { Colletotrichum lagenarium } \\
\text { Fusarium solani } \\
\text { Geotrichum candidum } \\
\text { Mycosphaerella fijiensis } \\
\text { Phytophthor apalmivora } \\
\text { Phytophthor acinnamomi } \\
\text { Rhizoctonia solani } \\
\text { Sclerotinia sclerotiorum } \\
\text { Trichoderma viride } \\
\text { Verticillium dahliae }\end{array}$ & $\begin{array}{c}\text { 1,8-cineole (470-82-6) } \\
\text { 1-methyl-1,4-cyclohexadiene } \\
\text { (4313-57-9) }\end{array}$ & $\begin{array}{l}\mathrm{C}_{10} \mathrm{H}_{18} \mathrm{O} \\
\mathrm{C}_{7} \mathrm{H}_{10}\end{array}$ & Persea indica & [65] \\
\hline
\end{tabular}


Table 1. Cont

\begin{tabular}{|c|c|c|c|c|c|c|}
\hline $\begin{array}{l}\text { Endophytic Fungi } \\
\text { Producing VOCs }\end{array}$ & VOCs Effects & $\begin{array}{l}\text { Microorganisms Inhibited } \\
\text { by VOCs }\end{array}$ & VOCs/CAS Number & Molecular Formula & Hosts & References \\
\hline \multirow{6}{*}{ Muscodor albus } & $\begin{array}{l}\text { Complete inhibition } \\
\text { of mycelium growth }\end{array}$ & $\begin{array}{l}\text { Pythium ultimum } \\
\text { Rhizoctonia solani } \\
\text { Tapesia yallundae }\end{array}$ & Methylacetate (79-20-9) & $\mathrm{C}_{3} \mathrm{H}_{6} \mathrm{O}_{2}$ & \multirow{6}{*}{ Cinnamomum zeylanicum } & [39] \\
\hline & $\begin{array}{l}\text { Inhibition of } \\
\text { mycelium }\end{array}$ & $\begin{array}{c}\text { Botrytis cinerea } \\
\text { Monilinia fructicola } \\
\text { Penicillium expansum }\end{array}$ & $\begin{array}{l}\text { 2-methyl-1-butanol (137-32-6) } \\
\text { 2-methylpropionic acid (79-31-2) }\end{array}$ & $\begin{array}{l}\mathrm{C}_{5} \mathrm{H}_{12} \mathrm{O} \\
\mathrm{C}_{4} \mathrm{H}_{8} \mathrm{O}\end{array}$ & & [66] \\
\hline & $\begin{array}{l}\text { Inhibition of } \\
\text { mycelium }\end{array}$ & $\begin{array}{l}\text { Aspergillus ochraceus } \\
\text { Fusarium solani } \\
\text { Rhizoctonia solani } \\
\text { Sclerotinia sclerotiorum }\end{array}$ & 2-methylpropionic acid (79-31-2) & $\mathrm{C}_{4} \mathrm{H}_{8} \mathrm{O}_{2}$ & & [67] \\
\hline & $\begin{array}{l}\text { Inhibits the } \\
\text { germination of } \\
\text { teliospores }\end{array}$ & $\begin{array}{l}\text { Tilletia horrida } \\
\text { Tilletia indica } \\
\text { Tilletia tritici }\end{array}$ & Unknown & & & [68] \\
\hline & $\begin{array}{l}\text { Inhibition of } \\
\text { mycelium growth }\end{array}$ & $\begin{array}{l}\text { Helminthosporium solani } \\
\text { Fusarium sambucinum }\end{array}$ & $\begin{array}{l}\text { 2-methylpropionic acid (79-31-2) } \\
\text { 3-methyl-1-butanol (123-51-3) } \\
\text { Ethyl alcohol (64-17-5) }\end{array}$ & $\begin{array}{l}\mathrm{C}_{4} \mathrm{H}_{8} \mathrm{O}_{2} \\
\mathrm{C}_{5} \mathrm{H}_{12} \mathrm{O} \\
\mathrm{C}_{2} \mathrm{H}_{6} \mathrm{O}\end{array}$ & & [69] \\
\hline & $\begin{array}{l}\text { Complete inhibition } \\
\text { of mycelium growth }\end{array}$ & $\begin{array}{l}\text { Aspergillus } s p \\
\text { Colletotrichum } s p \\
\text { Geotrichum } s p .\end{array}$ & $\begin{array}{l}\text { N-methyl-N-nitrosoisobutyramide } \\
\text { (1255641-06-5) }\end{array}$ & $\mathrm{C}_{5} \mathrm{H}_{10} \mathrm{~N}_{2} \mathrm{O}_{2}$ & & [46] \\
\hline
\end{tabular}


Table 1. Cont.

\begin{tabular}{|c|c|c|c|c|c|c|}
\hline $\begin{array}{l}\text { Endophytic Fungi } \\
\text { Producing VOCs }\end{array}$ & VOCs Effects & $\begin{array}{c}\text { Microorganisms Inhibited } \\
\text { by VOCs }\end{array}$ & VOCs/CAS Number & Molecular Formula & Hosts & References \\
\hline Muscodor musae & & $\begin{array}{l}\text { Alternaria porri } \\
\text { Alternaria solani } \\
\text { Aspergillus flavus }\end{array}$ & & $\mathrm{C}_{4} \mathrm{H}_{8} \mathrm{O}_{2}$ & Musa acuminata & \\
\hline Muscodor equiseti & & $\begin{array}{l}\text { Botrytis cinerea } \\
\text { Colletotrichum capsic } \\
\text { Colletotrichum gloeosporioides } \\
\text { Colletotrichum musae } \\
\text { Fusarium oxysporum } \\
\text { Fusarium solani } \\
\text { Nigrospora oryzae }\end{array}$ & Isobutyric acid (79-31-2) & $\begin{array}{l}\mathrm{C}_{5} \mathrm{H}_{12} \mathrm{O} \\
\mathrm{C}_{7} \mathrm{H}_{14} \mathrm{O}_{2}\end{array}$ & Equisetum debile & \\
\hline Muscodor oryzae & $\begin{array}{l}\text { Inhibition of } \\
\text { mycelium }\end{array}$ & $\begin{array}{l}\text { Penicillium digitatum } \\
\text { Penicillium expansum } \\
\text { Rhizoctonia solani } \\
\text { Sclerotium rolfsii } \\
\text { Candida albicans }\end{array}$ & $\begin{array}{c}\text { 3-methyl-1-butanol (123-51-3) } \\
\text { Ethyl-2-methylbutyrate } \\
\text { (7452-79-1) }\end{array}$ & & Oryza rufipogon & [35] \\
\hline Muscodor cinnamomi & & $\begin{array}{c}\text { Cryptococcus neoformans } \\
\text { Escherichia coli } \\
\text { Enterococcus faecalis } \\
\text { Proteus mirabilis } \\
\text { Staphylococcus aureus } \\
\text { Streptococcus pneumoniae }\end{array}$ & & & C. bejolghota & \\
\hline Muscodor suthepensis & & & & & C. bejolghota & \\
\hline
\end{tabular}


Table 1. Cont.

\begin{tabular}{|c|c|c|c|c|c|c|}
\hline $\begin{array}{l}\text { Endophytic Fungi } \\
\text { Producing VOCs }\end{array}$ & VOCs Effects & $\begin{array}{c}\text { Microorganisms Inhibited } \\
\text { by VOCs }\end{array}$ & VOCs/CAS Number & Molecular Formula & Hosts & References \\
\hline Muscodor Darjeelingensis & $\begin{array}{l}\text { Inhibition of } \\
\text { mycelium }\end{array}$ & $\begin{array}{c}\text { Alternaria alternata } \\
\text { Arthrinium phaeospermum } \\
\text { Aspergillus flavus } \\
\text { Aspergillus niger } \\
\text { Bionectria ochroleuca } \\
\text { Botrytis cinerea MTCC } 359 \\
\text { Cercospora beticola } \\
\text { Colletotrichum gloeosporioides } \\
\text { MTCC 9623 } \\
\text { Fusarium solani } \\
\text { Fusarium oxysporum } \\
\text { Lasiodiplodia theobromae } \\
\text { Muscodor albu scz620 } \\
\text { Penicillium chrysogenum } \\
\text { Rhizoctonia solani } \\
\text { Talaromyces marneffei } \\
\text { Candida glabrata } \\
\text { Candida viswanathii } \\
\text { Pseudomonas aeruginosa } \\
\text { MTCC } 3541 \\
\text { Pseudomonas aeruginosa } \\
\text { MTCC } 647 r \\
\text { Staphylococcus epidermidis } \\
\text { MTCC 2639 }\end{array}$ & $\begin{array}{c}\text { Isobutyric acid (79-31-2) } \\
\text { 3-methyl-1-butanol (123-51-3) } \\
\text { Ethyl-2-methyl-butyrate } \\
\text { (7452-79-1) }\end{array}$ & $\begin{array}{l}\mathrm{C}_{4} \mathrm{H}_{8} \mathrm{O}_{2} \\
\mathrm{C}_{5} \mathrm{H}_{12} \mathrm{O} \\
\mathrm{C}_{7} \mathrm{H}_{14} \mathrm{O}_{2}\end{array}$ & C. camphora & [70] \\
\hline
\end{tabular}


Table 1. Cont

\begin{tabular}{|c|c|c|c|c|c|c|}
\hline $\begin{array}{l}\text { Endophytic Fungi } \\
\text { Producing VOCs }\end{array}$ & VOCs Effects & $\begin{array}{l}\text { Microorganisms Inhibited } \\
\text { by VOCs }\end{array}$ & VOCs/CAS Number & Molecular Formula & Hosts & References \\
\hline Muscodor kashyum & $\begin{array}{l}\text { Inhibition of } \\
\text { mycelium growth }\end{array}$ & $\begin{array}{c}\text { Alternaria alternata } \\
\text { MTCC5432 } \\
\text { Agaricus bisporus } \\
\text { Aspergillus japonicus } \\
\text { Bionectria ochroleuca } \\
\text { Candida albicans } \\
\text { Cercospora beticola } \\
\text { Chaetomium heterosporum } \\
\text { Colletrotrichum gloeosporioides } \\
\text { Curvularia lunata } \\
\text { Fusarium equiseti } \\
\text { Fusarium oxysporum } \\
\text { Lasiodiplodia theobromae } \\
\text { Muscodor albus CZ620 } \\
\text { Mycosphaerella fijiensis } \\
\text { Penicillium citreonigrum } \\
\text { Penicillium marneffei } \\
\text { Trichoderma viride } \\
\text { Pleurotus flabellatus }\end{array}$ & $\begin{array}{c}\text { cyclohex-3-en-1-ol (822-66-2) } \\
\beta \text {-Bisabolol (15352-77-9) }\end{array}$ & $\begin{array}{l}\mathrm{C}_{6} \mathrm{H}_{10} \mathrm{O} \\
\mathrm{C}_{15} \mathrm{H}_{26} \mathrm{O}\end{array}$ & Aegle marmelos & [36] \\
\hline Nodulisporium sp. & $\begin{array}{l}\text { Inhibition of } \\
\text { mycelium }\end{array}$ & $\begin{array}{c}\text { Aspergillus fumigatus } \\
\text { Aspergillus flavus } \\
\text { Botrytis cinerea } \\
\text { Colletotrichum lagenarium } \\
\text { Ceratocystis ulmi } \\
\text { Cercospora beticola } \\
\text { Fusarium solani } \\
\text { Geotrichumcandidum } \\
\text { Phytophthor apalmivora } \\
\text { Phytophthora cinnamoni } \\
\text { Pythium ultimum } \\
\text { Rhizoctonia solani } \\
\text { Sclerotinias clerotiorum } \\
\text { Trichoderma viridae } \\
\text { Verticillium dahlia }\end{array}$ & $\begin{array}{c}\text { 1-methyl-1,4-cyclohexadiene } \\
\text { (4313-57-9) } \\
\text { 2-methyl-1-pentanol (105-30-6) } \\
\text { 1-Heptanol (111-70-6) } \\
\text { 1-Octanol (111-87-5) }\end{array}$ & $\begin{array}{l}\mathrm{C}_{7} \mathrm{H}_{10} \\
\mathrm{C}_{6} \mathrm{H}_{14} \mathrm{O} \\
\mathrm{C}_{7} \mathrm{H}_{16} \mathrm{O} \\
\mathrm{C}_{8} \mathrm{H}_{18} \mathrm{O}\end{array}$ & & [54] \\
\hline
\end{tabular}


Table 1. Cont

\begin{tabular}{|c|c|c|c|c|c|c|}
\hline $\begin{array}{l}\text { Endophytic Fungi } \\
\text { Producing VOCs }\end{array}$ & VOCs Effects & $\begin{array}{c}\text { Microorganisms Inhibited } \\
\text { by VOCs }\end{array}$ & VOCs/CAS Number & Molecular Formula & Hosts & References \\
\hline $\begin{array}{l}\text { Nodulisporium sp. } \\
\text { CMU-UPE34 }\end{array}$ & $\begin{array}{l}\text { Inhibition of } \\
\text { mycelium growth }\end{array}$ & $\begin{array}{c}\text { Alternaria porri } \\
\text { Alternaria solani } \\
\text { Colletotrichum capsici } \\
\text { Colletotrichum musae } \\
\text { Colletotrichum gloeosporioides } \\
\text { Fusarium oxysporum } \\
\text { Penicillium digitatum } \\
\text { Penicillium expansum } \\
\text { Nigrospora oryzae } \\
\text { Rhizoctonia solani } \\
\text { Sclerotium rolfsii }\end{array}$ & $\begin{array}{c}\text { 1,2,4-trimethylenecyclo-hexane } \\
\text { (2234-75-5) } \\
\text { 3-methyl-1-butanol (123-51-3) } \\
\text { Limonene (138-86-3) } \\
\text { Eucalyptol (synonym: } \\
\text { 1,8-cineole) (470-82-6) } \\
\text { ß-myrcene (123-35-3) } \\
\text { Terpinen-4-ol (562-74-3) }\end{array}$ & $\begin{array}{c}\mathrm{C}_{9} \mathrm{H}_{18} \\
\mathrm{C}_{5} \mathrm{H}_{12} \mathrm{O} \\
\mathrm{C}_{10} \mathrm{H}_{16} \\
\mathrm{C}_{10} \mathrm{H}_{18} \mathrm{O} \\
\mathrm{C}_{10} \mathrm{H}_{16} \\
\mathrm{C}_{10} \mathrm{H}_{18} \mathrm{O}\end{array}$ & & [48] \\
\hline $\begin{array}{c}\text { Oxyporus latem arginatus } \\
\text { EF069 }\end{array}$ & $\begin{array}{l}\text { Inhibition of } \\
\text { mycelium growth }\end{array}$ & $\begin{array}{c}\text { Alternaria alternata } \\
\text { Botrytis cinerea } \\
\text { Colletotrichum gloeosporioides } \\
\text { Fusarium oxysporum f.sp. } \\
\text { lycopersici }\end{array}$ & 2-Furanmethanol (90200-14-9) & $\mathrm{C}_{8} \mathrm{H}_{12} \mathrm{O}_{4}$ & Capsicum annum & [23] \\
\hline Phomopsis sp. & $\begin{array}{l}\text { Inhibition of } \\
\text { mycelium growth }\end{array}$ & $\begin{array}{l}\text { Aspergillus fumigatus } \\
\text { Ceratocystis ulmi } \\
\text { Colletotrichum lagenarium } \\
\text { Geotrichum candidum } \\
\text { Phytophthora palmivora } \\
\text { Pythium ultimum } \\
\text { Rhizoctonia solani } \\
\text { Sclerotinia sclerotiorum }\end{array}$ & $\begin{array}{c}\text { Sabinene (3387-41-5) } \\
\text { 3-methy-1-butanol (123-51-3) } \\
\text { 1-Propanol (71-23-8) } \\
\text { 2-Propanone (67-64-1) }\end{array}$ & $\begin{array}{l}\mathrm{C}_{10} \mathrm{H}_{16} \\
\mathrm{C}_{5} \mathrm{H}_{12} \mathrm{O} \\
\mathrm{C}_{3} \mathrm{H}_{8} \mathrm{O} \\
\mathrm{C}_{3} \mathrm{H}_{6} \mathrm{O}\end{array}$ & Odontoglossum sp. & [56] \\
\hline Trichoderma harzianum T-E5 & $\begin{array}{c}\text { Inhibition of } \\
\text { mycelium growth }\end{array}$ & $\begin{array}{l}\text { Fusarium oxysporum f.sp. } \\
\text { cucumerinum (FOC) }\end{array}$ & Diterpene (146985-82-2) & $\mathrm{C}_{20} \mathrm{H}_{30} \mathrm{O}_{4}$ & Cucumis sativus * & {$[26,71]$} \\
\hline Trichoderma saturnisporum & \multirow{3}{*}{$\begin{array}{l}\text { Inhibition of } \\
\text { mycelium growth }\end{array}$} & \multirow{3}{*}{ Colletotrichum capsici } & \multirow{3}{*}{$\begin{array}{l}\text { Ethylene (74-85-1) } \\
\text { Hydrogen cyanide (74-90-8) }\end{array}$} & \multirow{3}{*}{$\begin{array}{l}\mathrm{C}_{2} \mathrm{H}_{4} \\
\mathrm{CHN}\end{array}$} & Capsicum frutescence) * & \multirow{3}{*}{ [25] } \\
\hline Trichoderma reesei & & & & & Capsicum frutescence ${ }^{*}$ & \\
\hline Trichodermaharzianum & & & & & Capsicum frutescence ${ }^{*}$ & \\
\hline Trichoderma viride & $\begin{array}{c}\text { Inhibition of } \\
\text { mycelium growth }\end{array}$ & $\begin{array}{c}\text { Botrytis cinerea } \\
\text { Fusarium oxysporum }\end{array}$ & $\begin{array}{c}\text { 6-pentyl-2H-Pyran-2-one } \\
(27593-23-3)\end{array}$ & $\mathrm{C}_{10} \mathrm{H}_{14} \mathrm{O}_{2}$ & Capsicum frutescence * & [72] \\
\hline Trichoderma harzianum & $\begin{array}{l}\text { Induces the } \\
\text { expression of tomato } \\
\text { defense genes related } \\
\text { to salicylic acid (SA) }\end{array}$ & Botrytis cinerea & Diterpene (146985-82-2) & $\mathrm{C}_{20} \mathrm{H}_{30} \mathrm{O}_{4}$ & Solanum lycopersicum * & [73] \\
\hline
\end{tabular}

* Fusarium oxysporum and Trichoderma sp. were found in various plant. Examples of theses hosts are presented in the table. 


\section{Conclusions}

This review summarizes literature regarding the bioactivity of volatile substances produced by endophytic fungi. There is a consensus that VOCs emitted by endophytic fungi lead to partial or total inhibition of pathogenic fungi growth. To this end, the emission of antifungal VOCs appears to be a promising way to limit the use of pesticides for controlling fungal plant pathogens. However, it is important to mention that the antimicrobial activity of VOCs depends closely on their origin, dose, and application form. Currently, the great bioactivity potential of these compounds is drawing the attention of industry to commercialize VOC products for agricultural applications. However, multiple efforts need to be launched for the industrial production of theses formulations. Fungal VOCs are emitted in small quantities which could prevent their commercialization. In order to promote VOCs products, more studies must focus on determining the appropriate methods to ensure the greatest cost-effectiveness ratio. Ultimately, by using genetic tools, key genes involved in VOCs biosynthetic pathways can be identified and over-expressed for large-scale production of these compounds. Since a number of reports highlighted the phytotoxicty of some VOCs, more studies need to be conducted to safely use these molecules for biofumigation. Moreover, the toxicity of VOCs for humans needs to be strictly evaluated before their use in biocontrol strategies.

As endophytic fungi are abundant and have high genetic diversity, the identification and characterization of novel VOCs is a current research topic.

Author Contributions: A.K. conceived and designed the article; A.K, M.L.F., K.S., B.N. and M.H.J. wrote the paper. Funding: This research received no external funding.

Conflicts of Interest: The authors declare no conflict of interest.

\section{References}

1. Toth, S.J.; Buhler, W.G. Environmental Effects of Pesticides; Department of Entomology and Horticultural Science, North Carolina State University: Raleigh, NC, USA, 2009.

2. Tiryaki, O.; Temur, C. The fate of pesticide in the environment. J. Biol. Environ. Sci. 2010, 4, 29-38.

3. Kevan, P.G.; Shipp, L. Biological control as and biotechnological amelioration and ecosystem intensification in managed ecosystems. In Reference Module in Life Sciences; Elsevier: Amsterdam, The Netherlands, 2017; ISBN 978-0-12-809633-8.

4. Tripathi, P.; Dubey, N. Exploitation of natural products as an alternative strategy to control postharvest fungal rotting of fruit and vegetables. Postharvest Biol. Technol. 2004, 32, 235-245. [CrossRef]

5. Chen, J.-L.; Sun, S.-Z.; Miao, C.-P.; Wu, K.; Chen, Y.-W.; Xu, L.-H.; Guan, H.-L.; Zhao, L.-X. Endophytic Trichoderma gamsii yim ph30019: A promising biocontrol agent with hyperosmolar, mycoparasitism, and antagonistic activities of induced volatile organic compounds on root-rot pathogenic fungi of Panax notoginseng. J. Ginseng Res. 2016, 40, 315-324. [CrossRef] [PubMed]

6. Morath, S.U.; Hung, R.; Bennett, J.W. Fungal volatile organic compounds: A review with emphasis on their biotechnological potential. Fungal Biol. Rev. 2012, 26, 73-83. [CrossRef]

7. Rodriguez, R.; White, J., Jr.; Arnold, A.E.; Redman, R.S. Fungal endophytes: Diversity and functional roles. New Phytol. 2009, 182, 314-330. [CrossRef]

8. Dutta, D.; Puzari, K.C.; Gogoi, R.; Dutta, P. Endophytes: Exploitation as a tool in plant protection. Braz. Arch. Biol. Technol. 2014, 57, 621-629. [CrossRef]

9. Jia, M.; Chen, L.; Xin, H.-L.; Zheng, C.-J.; Rahman, K.; Han, T.; Qin, L.-P. A friendly relationship between endophytic fungi and medicinal plants: A systematic review. Front. Microbiol. 2016, 7, 906. [CrossRef]

10. Garnica-Vergara, A.; Barrera-Ortiz, S.; Muñoz-Parra, E.; Raya-González, J.; Méndez-Bravo, A.; Macías-Rodríguez, L.; Ruiz-Herrera, L.F.; López-Bucio, J. The volatile 6-pentyl-2h-pyran-2-one from Trichoderma atroviride regulates arabidopsis thaliana root morphogenesis via auxin signaling and ethylene insensitive 2 functioning. New Phytol. 2016, 209, 1496-1512. [CrossRef] [PubMed]

11. Li, R.; Li, J.; Zhou, Z.; Guo, Y.; Zhang, T.; Tao, F.; Hu, X.; Liu, W. Antibacterial and antitumor activity of secondary metabolites of endophytic fungi ty5 from Dendrobium officinale. J. Biobased Mater. Bioenergy 2018, 12, 184-193. [CrossRef] 
12. Korpi, A.; Järnberg, J.; Pasanen, A.-L. Microbial volatile organic compounds. Crit. Rev. Toxicol. 2009, 39, 139-193. [CrossRef] [PubMed]

13. Dudareva, N.; Negre, F.; Nagegowda, D.A.; Orlova, I. Plant volatiles: Recent advances and future perspectives. Criti. Rev. Plant Sci. 2006, 25, 417-440. [CrossRef]

14. Kharwar, R.; Upadhyay, R.; Dubey, N.; Raghuwanshi, R. Microbial Diversity and Biotechnology in Food Security; Springer: New Delhi, India, 2014.

15. Kaddes, A.; Parisi, O.; Berhal, C.; Ben Kaab, S.; Fauconnier, M.L.; Nasraoui, B.; Jijakli, M.H.; Massart, S.; De Clerck, C. Evaluation of the effect of two volatile organic compounds on barley pathogens. Molecules 2016, 21, 1124. [CrossRef]

16. Stinson, M.; Ezra, D.; Hess, W.M.; Sears, J.; Strobel, G. An endophytic Gliocladium sp. of Eucryphia cordifolia producing selective volatile antimicrobial compounds. Plant Sci. 2003, 165, 913-922. [CrossRef]

17. Stinson, A.M.; Zidack, N.K.; Strobel, G.A.; Jacobsen, B.J. Mycofumigation with muscodor albus and muscodor roseus for control of seedling diseases of sugar beet and verticillium wilt of eggplant. Plant Dis. 2003, 87, 1349-1354. [CrossRef]

18. Pagans, E.; Font, X.; Sánchez, A. Emission of volatile organic compounds from composting of different solid wastes: Abatement by biofiltration. J. Hazard. Mater. 2006, 131, 179-186. [CrossRef]

19. Pichersky, E.; Noel, J.P.; Dudareva, N. Biosynthesis of plant volatiles: Nature's diversity and ingenuity. Science 2006, 311, 808-811. [CrossRef] [PubMed]

20. Dudareva, N.; Klempien, A.; Muhlemann, J.K.; Kaplan, I. Biosynthesis, function and metabolic engineering of plant volatile organic compounds. New Phytol. 2013, 198, 16-32. [CrossRef] [PubMed]

21. Delory, B.M.; Delaplace, P.; du Jardin, P.; Fauconnier, M.-L. Barley (Hordeum distichon L.) roots synthesise volatile aldehydes with a strong age-dependent pattern and release (e)-non-2-enal and (e, z)-nona-2, 6-dienal after mechanical injury. Plant Physiol. Biochem. 2016, 104, 134-145. [CrossRef] [PubMed]

22. Farré-Armengol, G.; Filella, I.; Llusia, J.; Peñuelas, J. Bidirectional interaction between phyllospheric microbiotas and plant volatile emissions. Trends Plant Sci. 2016, 21, 854-860. [CrossRef]

23. Lee, S.O.; Kim, H.Y.; Choi, G.J.; Lee, H.B.; Jang, K.S.; Choi, Y.H.; Kim, J.C. Mycofumigation with Oxyporus latemarginatus ef069 for control of postharvest apple decay and rhizoctonia root rot on moth orchid. J. Appl. Microbiol. 2009, 106, 1213-1219. [CrossRef] [PubMed]

24. Malmierca, M.; Cardoza, R.; Alexander, N.; McCormick, S.; Hermosa, R.; Monte, E.; Gutiérrez, S. Involvement of Trichoderma trichothecenes in the biocontrol activity and in the induction of plant defense related genes. Appl. Environ. Microbiol. 2012, 78, 4856-4868. [CrossRef]

25. Ajith, P.S.; Lakshmidevi, N. Effect of volatile and non-volatile compounds from trichoderma spp. Against colletotrichum capsici incitant of anthracnose on bell peppers. Nat. Sci. 2010, 8, 265-269.

26. Zhang, F.; Yang, X.; Ran, W.; Shen, Q. Fusarium oxysporum induces the production of proteins and volatile organic compounds by Trichoderma harzianum t-e5. FEMS Microbiol. Lett. 2014, 359, 116-123. [CrossRef] [PubMed]

27. Worapong, J. Muscodor albus anam. Gen. Et sp. Nov., an endophyte from Cinnamomum zeylanicum. Mycotaxon 2001, 79, 67-79.

28. Worapong, J.; Strobel, G.; Daisy, B.; Castillo, U.F.; Baird, G.; Hess, W. Muscodor roseus anam. Sp. Nov., an endophyte from grevillea pteridifolia. Mycotaxon 2002, 81, 463-475.

29. Daisy, B.; Strobel, G.; Ezra, D.; Castillo, U.; BAIRD, G.; Hess, W. Muscodor vitigenus anam. Sp. Nov., an endophyte from paullinia paullinioides. Mycotaxon 2002, 84, 39-50.

30. Mitchell, A. Muscodor crispans, a novel endophyte from ananas ananassoides in the bolivian amazon. Fung. Divers. 2008, 31, 37-43.

31. González, M.C.; Anaya, A.L.; Glenn, A.E.; Macías-Rubalcava, M.L.; Hernández-Bautista, B.E.; Hanlin, R.T. Muscodor yucatanensis, a new endophytic ascomycete from mexican chakah, Bursera simaruba. Mycotaxon 2009, 110, 363-372. [CrossRef]

32. Zhang, C.-L.; Wang, G.-P.; Mao, L.-J.; Komon-Zelazowska, M.; Yuan, Z.-L.; Lin, F.-C.; Druzhinina, I.S.; Kubicek, C.P. Muscodor fengyangensis sp. Nov. From southeast china: Morphology, physiology and production of volatile compounds. Fungal Biol. 2010, 114, 797-808. [CrossRef] [PubMed]

33. Suwannarach, N.; Bussaban, B.; Hyde, K.D.; Lumyong, S. Muscodor cinnamomi, a new endophytic species from Cinnamomum bejolghota. Mycotaxon 2010, 114, 15. [CrossRef] 
34. Kudalkar, P.; Strobel, G.; Riyaz-Ul-Hassan, S.; Geary, B.; Sears, J. Muscodor sutura, a novel endophytic fungus with volatile antibiotic activities. Mycoscience 2012, 53, 319-325. [CrossRef]

35. Suwannarach, N.; Kumla, J.; Bussaban, B.; Hyde, K.D.; Matsui, K.; Lumyong, S. Molecular and morphological evidence support four new species in the genus Muscodor from northern Thailand. Ann. Microbiol. 2013, 63, 1341-1351. [CrossRef]

36. Meshram, V.; Kapoor, N.; Saxena, S. Muscodor kashayum sp. Nov.-A new volatile anti-microbial producing endophytic fungus. Mycology 2013, 4, 196-204. [CrossRef]

37. Saxena, S.; Meshram, V.; Kapoor, N. Muscodor tigerii sp. Nov.-volatile antibiotic producing endophytic fungus from the northeastern himalayas. Ann. Microbiol. 2015, 65, 47-57. [CrossRef]

38. Mercier, J.; Jiménez-Santamaría, J.I.; Tamez-Guerra, P. Development of the volatile-producing fungus muscodor albus worapong, strobel, and hess as a novel antimicrobial biofumigant. Revista Mexicana de Fitopatología 2007, 25, 173-179.

39. Suwannarach, N.; Bussaban, B.; Nuangmek, W.; Pithakpol, W.; Jirawattanakul, B.; Matsui, K.; Lumyong, S. Evaluation of Muscodor suthepensis strain cmu-cib462 as a postharvest biofumigant for tangerine fruit rot caused by Penicillium digitatum. J. Sci. Food Agric. 2016, 96, 339-345. [CrossRef] [PubMed]

40. Ezra, D.; Hess, W.; Strobel, G.A. New endophytic isolates of Muscodor albus, a volatile-antibiotic-producing fungus. Microbiology 2004, 150, 4023-4031. [CrossRef]

41. Strobel, G.A.; Dirkse, E.; Sears, J.; Markworth, C. Volatile antimicrobials from Muscodor albus, a novel endophytic fungus. Microbiology 2001, 147, 2943-2950. [CrossRef]

42. Quimby, P., Jr.; Zidack, N.; Boyette, C.; Grey, W. A simple method for stabilizing and granulating fungi. Biocontrol Sci. Technol. 1999, 9, 5-8. [CrossRef]

43. Strobel, G.; Manker, D.C.; Mercier, J. Endophytic Fungi and Methods of Use. U.S. Patent No 6,911,338, 28 June 2005.

44. Lacey, L.; Horton, D.; Jones, D.; Headrick, H.; Neven, L. Efficacy of the biofumigant fungus Muscodor albus (Ascomycota: Xylariales) for control of codling moth (Lepidoptera: Tortricidae) in simulated storage conditions. J. Econ. Entomol. 2009, 102, 43-49. [CrossRef] [PubMed]

45. Morgenstern, R.D. Economic Analyses at Epa: Assessing Regulatory Impact; Routledge: Abingdon-on-Thames, UK, 2014.

46. Hutchings, M.L.; Hiller, D.A.; Berro, J.; Strobel, S.A. Mycofumigation through production of the volatile DNA methylating agent n-methyl-n-nitrosoisobutyramide by fungi in the genus Muscodor. J. Biol. Chem. 2017, 292, 7358-7371. [CrossRef]

47. Sánchez-Fernández, R.E.; Diaz, D.; Duarte, G.; Lappe-Oliveras, P.; Sánchez, S.; Macías-Rubalcava, M.L. Antifungal volatile organic compounds from the endophyte Nodulisporium sp. Strain gs4d2iila: A qualitative change in the intraspecific and interspecific interactions with pythium aphanidermatum. Microb. Ecol. 2016, 71,347-364. [CrossRef] [PubMed]

48. Suwannarach, N.; Kumla, J.; Bussaban, B.; Nuangmek, W.; Matsui, K.; Lumyong, S. Biofumigation with the endophytic fungus Nodulisporium spp. Cmu-upe34 to control postharvest decay of citrus fruit. Crop. Prot. 2013, 45, 63-70. [CrossRef]

49. Mends, M.T.; Yu, E.; Strobel, G.A.; Hassan, S.; Booth, E.; Geary, B.; Sears, J.; Taatjes, C.; Hadi, M. An endophytic Nodulisporium sp. Producing volatile organic compounds having bioactivity and fuel potential. J. Pet. Environ. Biotechnol. 2012, 3, 16. [CrossRef]

50. Schalchli, H.; Tortella, G.; Rubilar, O.; Parra, L.; Hormazabal, E.; Quiroz, A. Fungal volatiles: An environmentally friendly tool to control pathogenic microorganisms in plants. Crit. Rev. Biotechnol. 2016, 36, 144-152. [CrossRef] [PubMed]

51. Yu, D.; Wang, J.; Shao, X.; Xu, F.; Wang, H. Antifungal modes of action of tea tree oil and its two characteristic components against Botrytis cinerea. J. Appl. Microbiol. 2015, 119, 1253-1262. [CrossRef]

52. Worapong, J.; Strobel, G.A. Biocontrol of a root rot of kale by Muscodor albus strain mfc2. BioControl 2009, 54, 301-306. [CrossRef]

53. Park, M.-S.; Ahn, J.-Y.; Choi, G.-J.; Choi, Y.-H.; Jang, K.-S.; Kim, J.-C. Potential of the volatile-producing fungus Nodulisporium sp. Cf016 for the control of postharvest diseases of apple. Plant Pathol. J. 2010, 26, 253-259. [CrossRef] 
54. Riyaz-Ul-Hassan, S.; Strobel, G.; Geary, B.; Sears, J. An endophytic Nodulisporium sp. From central america producing volatile organic compounds with both biological and fuel potential. J. Microbiol. Biotechnol. 2013, 23, 29-35. [CrossRef]

55. Polizzi, V.; Fazzini, L.; Adams, A.; Picco, A.M.; De Saeger, S.; Van Peteghem, C.; De Kimpe, N. Autoregulatory properties of (+)-thujopsene and influence of environmental conditions on its production by Penicillium decumbens. Microb. Ecol. 2011, 62, 838. [CrossRef] [PubMed]

56. Singh, S.K.; Strobel, G.A.; Knighton, B.; Geary, B.; Sears, J.; Ezra, D. An endophytic Phomopsis sp. Possessing bioactivity and fuel potential with its volatile organic compounds. Microb. Ecol. 2011, 61, 729-739. [CrossRef] [PubMed]

57. Li, Q.; Wu, L.; Hao, J.; Luo, L.; Cao, Y.; Li, J. Biofumigation on post-harvest diseases of fruits using a new volatile-producing fungus of Ceratocystis fimbriata. PLoS ONE 2015, 10, e0132009. [CrossRef]

58. Arimura, G.-I.; Shiojiri, K.; Karban, R. Acquired immunity to herbivory and allelopathy caused by airborne plant emissions. Phytochemistry 2010, 71, 1642-1649. [CrossRef] [PubMed]

59. Muller, W.H. Volatile materials produced by Salvia leucophylla: Effects on seedling growth and soil bacteria. Bot. Gaz. 1965, 126, 195-200. [CrossRef]

60. Evans, H.; Crocoll, C.; Bajpai, D.; Kaur, R.; Feng, Y.-L.; Silva, C.; Carreón, J.T.; Valiente-Banuet, A.; Gershenzon, J.; Callaway, R.M. Volatile chemicals from leaf litter are associated with invasiveness of a neotropical weed in asia. Ecology 2011, 92, 316-324.

61. He, H.; Song, Q.; Wang, Y.; Yu, S. Phytotoxic effects of volatile organic compounds in soil water taken from a Eucalyptus urophylla plantation. Plant Soil 2014, 377, 203-215. [CrossRef]

62. Lee, S.; Hung, R.; Schink, A.; Mauro, J.; Bennett, J.W. Arabidopsis thaliana for testing the phytotoxicity of volatile organic compounds. Plant Growth Regul. 2014, 74, 177-186. [CrossRef]

63. Ogura, T.; Sunairi, M.; Nakajima, M. 2-methylisoborneol and geosmin, the main sources of soil odor, inhibit the germination of Brassicaceae seeds. Soil Sci. Plant Nutr. 2000, 46, 217-227. [CrossRef]

64. Zhang, Q.; Yang, L.; Zhang, J.; Wu, M.; Chen, W.; Jiang, D.; Li, G. Production of anti-fungal volatiles by non-pathogenic Fusarium oxysporum and its efficacy in suppression of verticillium wilt of cotton. Plant Soil 2015, 392, 101-114. [CrossRef]

65. Tomsheck, A.R.; Strobel, G.A.; Booth, E.; Geary, B.; Spakowicz, D.; Knighton, B.; Floerchinger, C.; Sears, J.; Liarzi, O.; Ezra, D. Hypoxylon sp., an endophyte of Persea indica, producing 1, 8-cineole and other bioactive volatiles with fuel potential. Microb. Ecol. 2010, 60, 903-914. [CrossRef] [PubMed]

66. Mercier, J.; Jiménez, J.I. Control of fungal decay of apples and peaches by the biofumigant fungus Muscodor albus. Postharvest Biol. Technol. 2004, 31, 1-8. [CrossRef]

67. Ezra, D.; Strobel, G.A. Effect of substrate on the bioactivity of volatile antimicrobials produced by Muscodor albus. Plant Sci. 2003, 165, 1229-1238. [CrossRef]

68. Goates, B.J.; Mercier, J. Effect of biofumigation with volatiles from Muscodor albus on the viability of Tilletia spp. Teliospores. Can. J. Microbiol. 2009, 55, 203-206. [CrossRef] [PubMed]

69. Corcuff, R.; Mercier, J.; Tweddell, R.; Arul, J. Effect of water activity on the production of volatile organic compounds by Muscodor albus and their effect on three pathogens in stored potato. Fungal Biol. 2011, 115, 220-227. [CrossRef]

70. Sanjai, S.; Vineet, M.; Neha, K. Muscodor darjeelingensis, a new endophytic fungus of Cinnamomum camphora collected from northeastern Himalayas. Sydowia 2014, 66, 55-67.

71. Cernava, T.; Aschenbrenner, I.A.; Grube, M.; Liebminger, S.; Berg, G. A novel assay for the detection of bioactive volatiles evaluated by screening of lichen-associated bacteria. Front. Microbiol. 2015, 6, 398. [CrossRef] [PubMed]

72. Schalchli, H.; Hormazabal, E.; Becerra, J.; Birkett, M.; Alvear, M.; Vidal, J.; Quiroz, A. Antifungal activity of volatile metabolites emitted by mycelial cultures of saprophytic fungi. Chem. Ecol. 2011, 27, 503-513. [CrossRef]

73. Malmierca, M.G.; McCormick, S.P.; Cardoza, R.E.; Alexander, N.J.; Monte, E.; Gutiérrez, S. Production of trichodiene by Trichoderma harzianum alters the perception of this biocontrol strain by plants and antagonized fungi. Environ. Microbiol. 2015, 17, 2628-2646. [CrossRef]

(C) 2019 by the authors. Licensee MDPI, Basel, Switzerland. This article is an open access article distributed under the terms and conditions of the Creative Commons Attribution (CC BY) license (http:/ / creativecommons.org/licenses/by/4.0/). 